\title{
Genetic analysis of some yield and quality traits in bread wheat (Triticum aestivum $\mathbf{L}$.)
}

Vichitra Kumar Arya ${ }^{1^{*}}$, Pradeep Kumar ${ }^{2}$, Jogendra Singh ${ }^{2}$, Lokendra Kumar ${ }^{2}$ and Amit Kumar Sharma ${ }^{2}$

${ }^{1}$ Sardar Vallabhbhai Patel University of Agriculture and Technology, Meerut, India

${ }^{2}$ ICAR-Indian Institute of Wheat and Barley Research, Karnal, India

\section{Article history}

Received: 28 July 2017

Revised : 01 December 2017

Accepted: 04 February 2018

\section{Citation}

Arya VK, P Kumar, J Singh, L Kumar and AK Sharma. 2018. Genetic analysis of some yield and quality traits in bread wheat (Triticum aestivum L.). Wheat and Barley Research 10(1): 25-32. doi.org/ 10.25174/22494065/2018/72641

\section{"Corresponding author}

Email: aryavichitra@gmail.com

(C) Society for Advancement of Wheat and Barley Research

\begin{abstract}
Forty five crosses derived from 10 diverse genotypes using diallel fashion were evaluated in 3-RBD for combining ability. Significant differences among treatments, parents, crosses and parent vs crosses were observed for all the traits studied. The results from the present study revealed that three parents viz., K 612, HUW 648 and WCW 95-1 were found to be good general combiners due to their high general combining ability effect. Cross combinations namely; K 612/K 910-4; K 612/WCW 95-1; K 612/NW 4081; K 612/NW 4035; HUW 648/AAI 13; HUW 648/HUW 658; HUW 648/K 307; HUW 648/K 910-30; AAI 13/ K 910-30, K 910-4/NW 4081; HUW 658/K 307; HUW 658/K 910-30; K 307/NW 4035; WCW 95-1/NW 4035 showed desired specific combining ability effect for grain yield along with some attributing traits. Thus, present study suggests that these cross combinations may be utilized in the development of high yielding genotypes with desirable traits for improving the bread wheat.
\end{abstract}

Keywords: Bread wheat, combining ability, diallel analysis

\section{Introduction}

Bread wheat (Triticum aestivum L. em Thell) is one of the important cereal crops for food security all over the world. As a staple food, it contributes about $36 \%$ of the world populations. Wheat offers nearly $55 \%$ wheat production has increased manifold from 6.60 million tonnes at the time of independence to 98.4 million tonnes in 2016-17. The productivity has scaled up $473 \%$ (Anonymous, 2017). The population of India is increasing at an alarming rate and by 2025; the country would require about 109 million tonnes of wheat to feed up its ever growing population, which is a major challenge under changing climatic scenario (FAO, 2010). Hence, enhancing wheat production is one of the strategies to meet out the domestic demand of the country. Continous increase in wheat productivity since the green revolution is associated with genetic improvement in yield potential, resistance to diseases and adaptation to abiotic stresses as well as better agronomic practices (Evenson and Gollin, 2003). The rising worldwide demand for wheat and limited availability of land is retaining pressure on breeding programs to offer elite cultivars that can acclimatize in wide range of agro-climatic conditions without compromising agronomic performance, grain quality, diseases resistance and tolerance to abiotic stresses. To accomplish the increasing demand of world population, wheat production and productivity must be enhanced. Hence, most important step in any breeding program is the identification of suitable parents with high general combining ability (GCA) and specific combining ability (SCA) for grain yield and to create genetic variability and gather information about the genetic architecture of component traits. 
The combining ability analysis provides information about the nature of gene action and relative magnitude of fixable and non-fixable genetic variances, which are useful for identification of superior parents for hybridization. Combining ability analysis was implied to study gene effect and genetic worth of parents in wheat by Romanus et al. (2008) and Kumar et al. (2015a). In addition, diallel analysis gives plant breeders the opportunity to choose the most efficient selection method by allowing them to estimate several genetic parameters (Singh and Chaudhary, 1979). Therefore, aim of the study was to identify the best combining parents on the basis of their general and specific combining ability for agromorphological and quality traits in bread wheat.

\section{Materials and methods}

The present study was carried out at Crop Research Centre of Sardar Vallabhbhai Patel University of Agriculture \& Technology, Meerut during 2012-13 and 2013-2014. Geographically, the experimental farm is located between $28^{\circ} 58^{\prime} \mathrm{N}$ latitude to $77^{\circ} 42^{\prime} \mathrm{E}$ longitude at $228 \mathrm{~m}$ above mean sea level has humid subtropical climate range of $26^{\circ} \mathrm{C}$ to $39^{\circ} \mathrm{C}$ and $8^{\circ} \mathrm{C}$ to $29^{\circ} \mathrm{C}$ in summer and winter seasons, respectively. The experimental material consisted of $45 \mathrm{~F}_{1} \mathrm{~s}$ and their ten parents. The crosses were made in diallel fashion (excluding reciprocals) by using 10 diverse genotypes of bread wheat viz; K 612, HUW 648, AAI 13, K 9104, HUW 658, K 307, WCW 95-1, K 910-30, NW 4081 and NW 4035 during 2012-2013.

Ten parents and their $45 \mathrm{~F}_{1} \mathrm{~s}$ were evaluated in randomized block design (RBD) with three replications. Each genotype was planted in 2-rows of 1 meters length (7-10 seeds in each row), inter and intra row distance was 25 and 10 $\mathrm{cm}$, respectively. All the standard agronomical practices were followed to raise the normal crop. The observations were recorded on five randomly selected competitive plants in each replication for plant height $(\mathrm{cm})$, number of productive tillers/plant, number of grains/spike, number of spikelets/spike, 1000-grain weight (g), biological yield/ plant $(\mathrm{g})$, grain yield/plant $(\mathrm{g})$, gluten content $(\%)$, ash content $(\%)$ and protein content $(\%)$ whereas days to 50 $\%$ flowering and days to maturity were recorded on all the plants in the plot. The differences between genotypes for all traits were tested for significance by using analysis of variance technique (Panse and Sukhatme, 1967). The combining ability was estimated by using the method-II and model-I as proposed by Griffing (1956b).

\section{Results and discussion}

The analysis of variance for 12 agro-morphological and quality traits under study is depicted in table 1. In present study, total variance was partitioned into different components namely, treatments, parents, crosses and parents vs. crosses were observed highly significant for all the traits except days to $50 \%$ flowering, days to maturity, grains/spike in parents while spikelets/spike and protein content in parents vs. crosses. Significance of variance for parents vs crosses indicted that crosses were quite different than parents. The ANOVA for combining ability (Table 2) indicated that variances due to general combining ability (GCA) were highly significant for plant height, 1000-grain weight, biological yield, grain yield, gluten, ash and protein content while significant for productive tillers/plant. Whereas specific combining ability (SCA) variance was highly significant for all the traits studied except grains/spike. Similar findings were also reported (Adel and Ali, 2013). In general, magnitude of SCA was greater than GCA variance for all the traits except plant height, biological yield, protein content and grain yield. The higher magnitude of SCA variance as compared to GCA variance has been reported for yield and its components (Siddique et al. 2004 and Srivastava et al. 2012). Significant variances due to general and specific combining ability for agro-morphological and quality traits indicated that both additive and nonadditive gene action are paramount in the present set of breeding materials. Similar findings were reported by Kumar et al. (2010).

The estimated value of $\delta^{2} \mathrm{~s}$ was higher than $\delta^{2} \mathrm{~g}$ for all the traits under study indicating predominance of non-additive gene action. The ratio of $\delta^{2} \mathrm{~g} / \delta^{2} \mathrm{~s}$ was less than unity (1.00) for all the agro-morphological and quality traits, suggesting the importance of non-additive gene action over additive gene action in the breeding material. Adel and Ali (2013) also reported the similar results in their study. The average degree of dominance $(\delta 2 \mathrm{~s} / \delta 2 \mathrm{~g}) 1 / 2$ was greater than unity (1.0) indicating over dominance for all the traits. Hassani et al. (2005) also reported the similar findings. In case of general combining ability effects of parents, none of the parent was identified as good general combiner for all the traits as given in table 3. All parents showed favourable GCA effect for one or other traits, but out of ten parents, three parents viz; K 612, HUW 648 and WCW 95-1 expressed favourable GCA effect for grain yield and also good for yield contributing traits. 


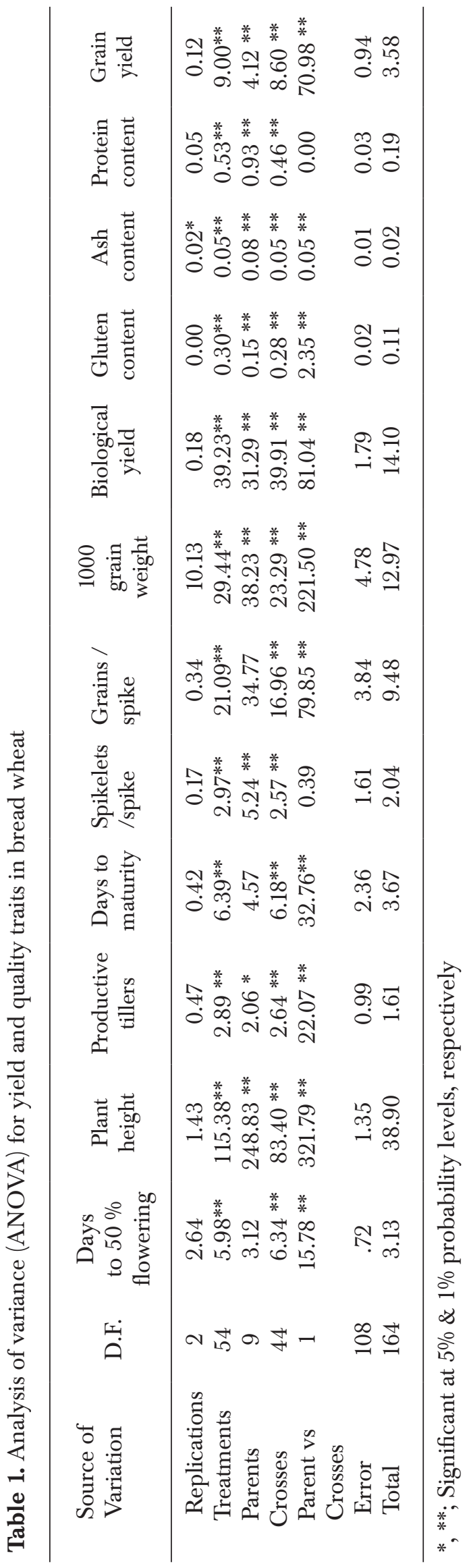

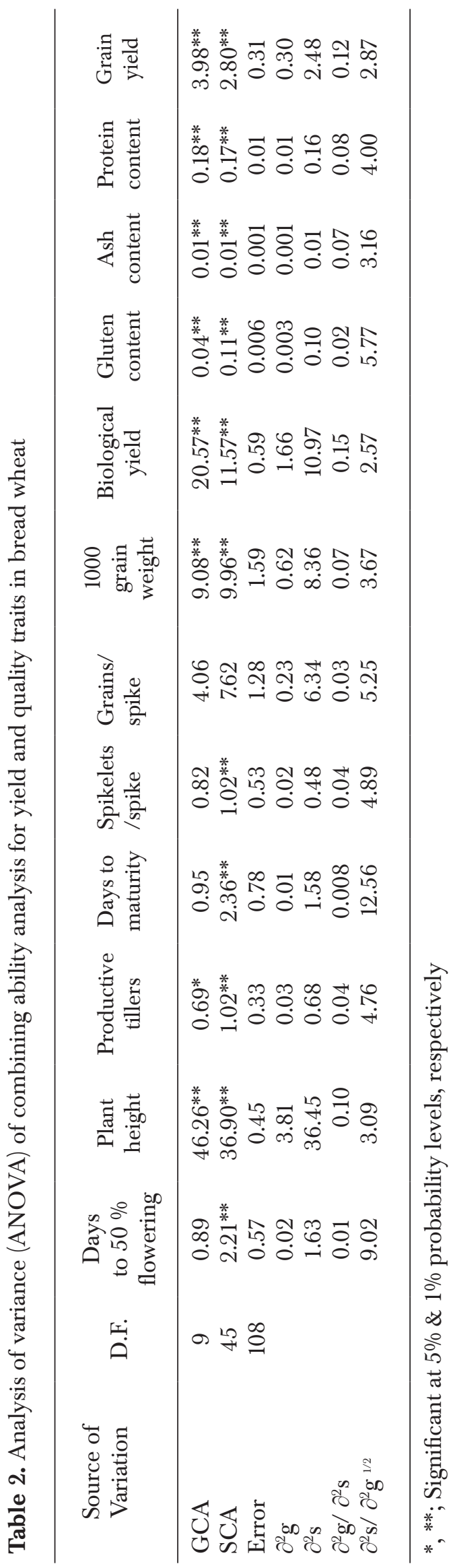




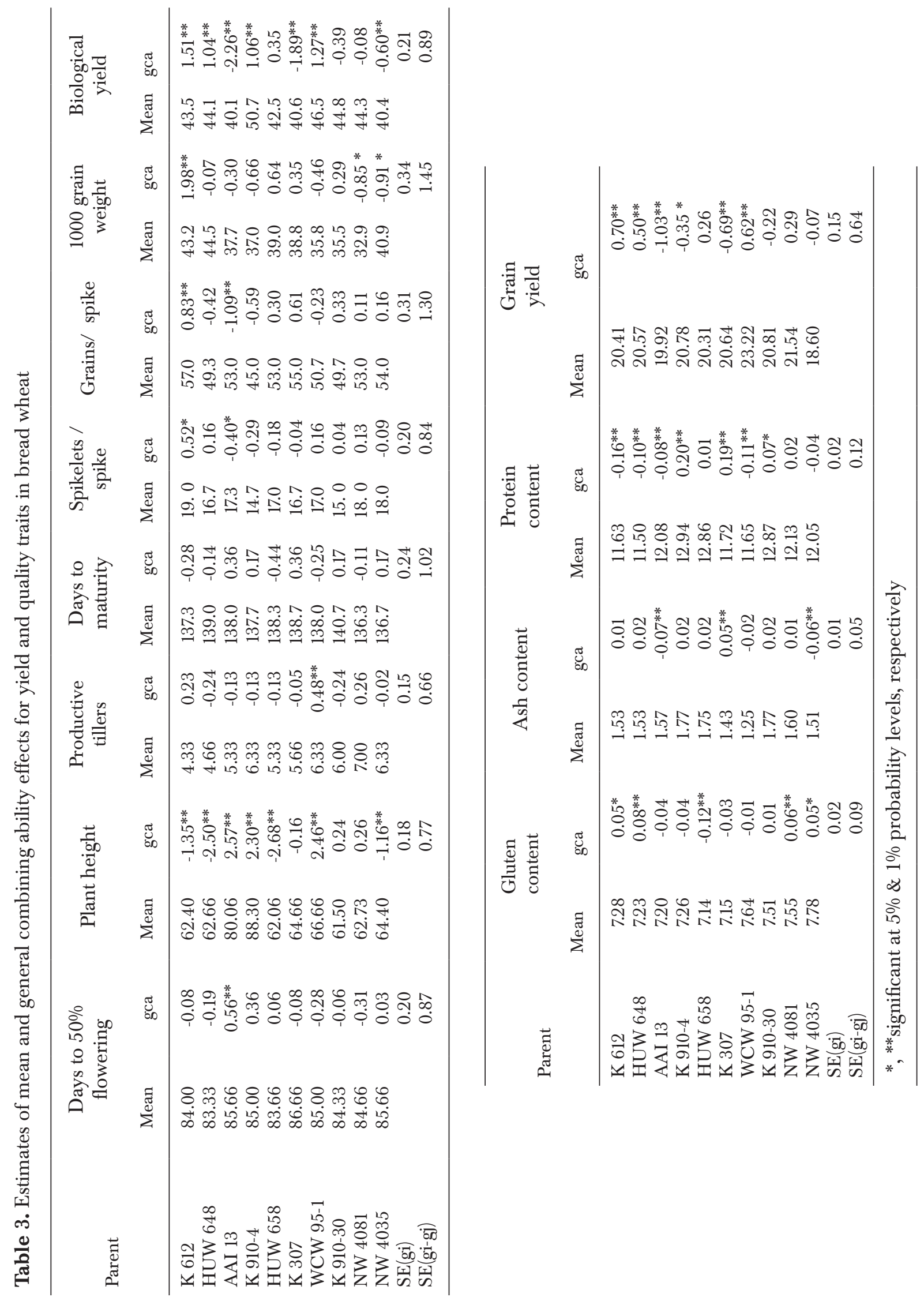




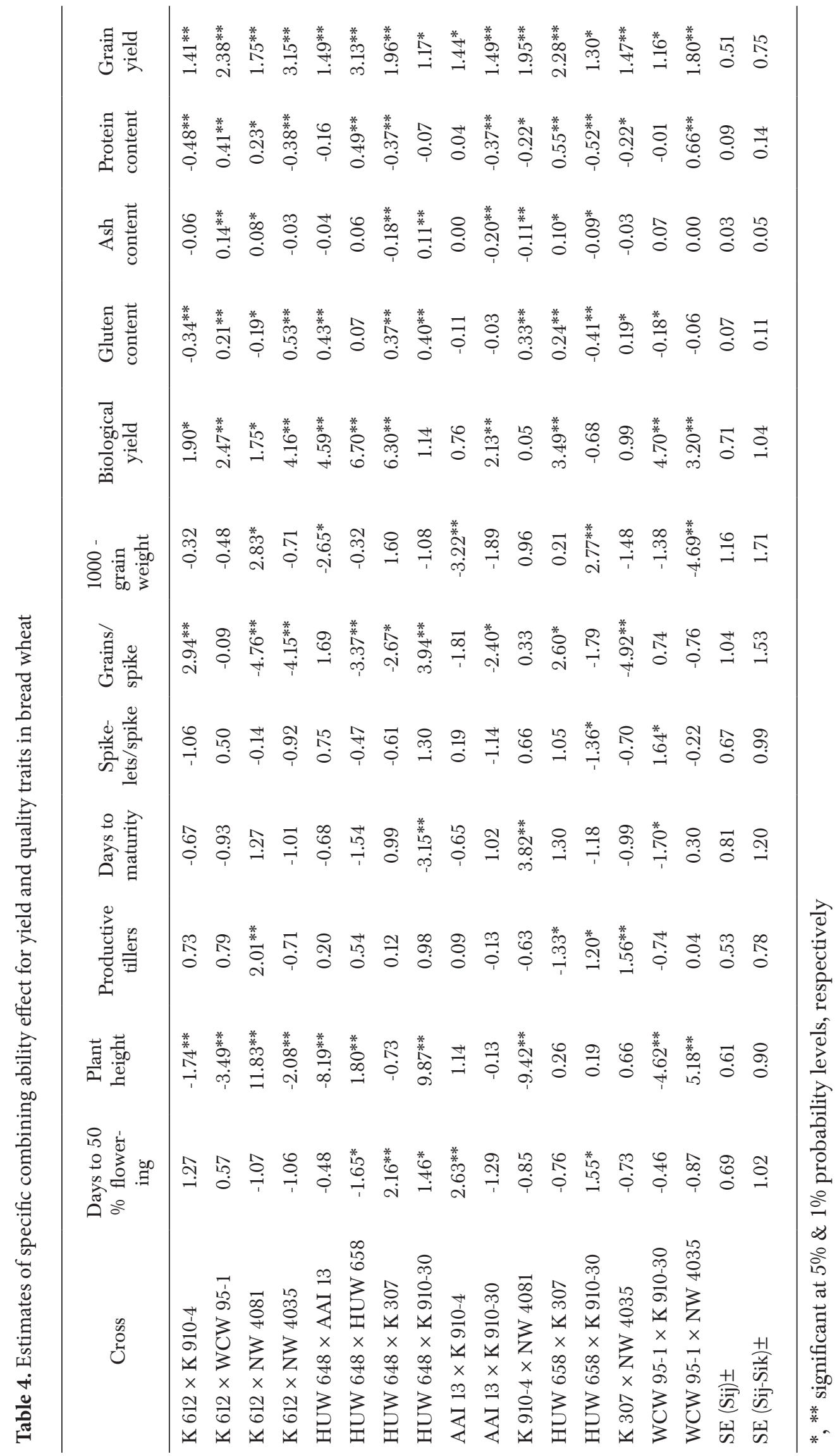




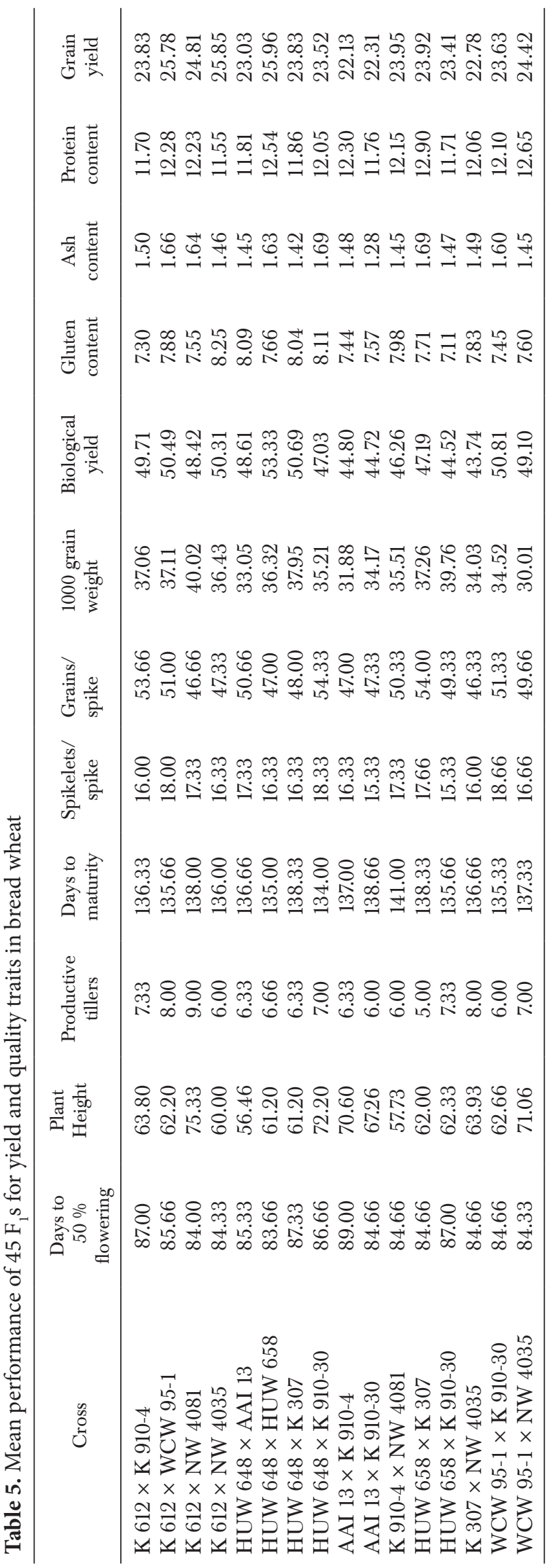

Therefore, these parents can be used in crossing programme for improving the grain yield in wheat. Similar findings were published by Ali and Falahy (2011). K 612 was good general combiner for grain yield which also ranked amongst the best varieties with regard to the per se grain yield/plant (GY). This parent exhibited high GCA effect for spikelets/spike, grains/ spike, 1000 grain weight, biological yield and gluten content. High GCA for plant height and biological yield was largely observed to contribute to the higher GCA for grain yield. HUW 648 expressed high GCA for plant height, biological yield, grain yield and gluten content while WCW 95-1 showed for plant height, productive tillers, biological yield and grain yield, suggested that these parents could be used as donor parent for the improvement of these traits. Srivastava et al. (2012) was also noticed similar results in their study. In most of the cases, performance of the parents bears direct reflection of their respective GCA effects, i.e., parents showing highest GCA effects for traits and also observed to be good performer with respect to the particular trait. The high GCA effects are mostly due to the additive gene effects or additive $\mathrm{x}$ additive interaction as reported by Griffing (1956). A number of parents were poor in GCA for grain yield, however, exhibited good GCA for contributing traits; these were AAI 13 (days to 50\% flowering and plant height), K 9104 (plant height, biological yield and protein content) and K 910-30 (protein content). In order to synthesize a dynamic population with most of the favourable genes accumulated; it will be pertinent to make use of these parents in multiple crossing programmes as these are good general combiners for several traits. Apart from conventional breeding methods relying upon additive or additive $\mathrm{x}$ additive types of gene action, population improvement methods appears to be a promising alternative.

Estimates of SCA effects revealed (Table 4) that out of 45 cross combinations, 8 for days to $50 \%$ flowering, 33 for plant height, 4 for productive tillers, 4 for days to maturity, 1 for spikelets/spike, 4 for grains/spike, 3 for 1000 grain weight, 16 for biological yield, 13 for grain yield, 17 for gluten content, 8 for ash content and 11 for protein content revealed desirable and highly significant SCA effects. The most promising cross combinations for each trait are shown in Table 5 . Some of the cross combinations exhibiting significant SCA effects for grain yield has significant SCA effect 
for some yield components as well. For instance, K 612 x NW 4035 possesses highest SCA effect for grain yield also consists of significant SCA for plant height, biological yield and gluten content, similarly, HUW 648 x HUW658 had highly significant for grain yield along with days to $50 \%$ flowering, plant height, biological yield and protein content.

Cross HUW 648 x K 307 showed highly significant SCA effect for grain yield with yield attributing traits viz; days to $50 \%$ flowering, biological yield and gluten content. These heterotic crosses involved parents belonging to high $x$ low general combiners. These findings indicate that it is not necessary to get best recombinants only from high $\mathrm{x}$ high general combiners as reported (Kulshreshtha and Singh, 2011). The most promising cross is the one that involves parents with high GCA and also reveals high SCA effects. The major portion of such variance would be fixable in crosses K 612 x K 910-4 and K 612 x WCW 95-1 for biological yield; K 612 x NW 4035 for gluten content and K612 x WCW 95-1 for grain yield/plant in later generations. The cross K612 x NW 4035 showed significant SCA effect though both the parents involved revealed low general combining ability effects for reducing the plant height. Similar findings were also reported (Singh et al. 2014; Kumar et al. 2015; Kumar et al. 2016) for grain yield, agro-morphological and quality traits in wheat.

The traits which show predominance of non-additive gene effects indicates that the improvement of such traits would be difficult, as simple pedigree breeding will not be able to fix the superior lines in the early generations. In such situation, maintaining considerable heterozygosity through mating of selected plants in early segregating generations could attain maximum gain. Therefore, few cycles of recurrent selection followed by pedigree breeding will be effective and useful for the improvement of yield in such cases in the present material. The present study demonstrates that both additive (fixable) and nonadditive (non-fixable) components of genetic variances were involved in governing the inheritance of almost all the quantitative and quality traits. Therefore, bi-parental mating and/or diallel selective mating which may allow intermating of the selects in different cycles and exploit both additive and non-additive gene effects could be useful in the genetic improvement of the characters of bread wheat. $F_{1}$ hybrids showing high SCA and having parents with good GCA into multiple crosses could also be a worthwhile approach for tangible improvement of grain yield in spring wheat.

\section{References}

1. Adel MM and EA Ali. 2013. Gene action and combining ability in six parental diallel cross of wheat. Asian Journal of crop science 5:14-23.

2. Ali IH and MAH Falahy. 2011. Analysis of partial diallel crosses for yield and its components in durum wheat. Bulletin of Faculty of Agriculture Cairo-University 62:145-152.

3. Anonymous. 2017. Annual Report 2016-17, ICARIndian Institute of Wheat \& Barley Research, Karnal-132001, Haryana, India.

4. Breiman A and D Graur. 1995. Wheat evaluation. Israel Journal of Plant Sciences 43:58-95.

5. Evenson RE and D Gollin. 2003. Accessing the impact of green revolution. Science 300:758-62.

6. FAO. 2010.The state of food insecurity in the world addressing food insecurity in protracted crisis. Food and Agriculture Organization of the United Nations, http://www.fao.org/docrep/013/il863e/il683e.pdf

7. Griffing B. 1956b. Concept of general and specific combining ability in relation to diallel crossing systems. Australian Journal of Biological Sciences 9:463493.

8. Hayman BI . 1954. The theory and analysis of diallel crosses. Genetics 39:789-809.

9. Hassani M, G Saeidi and A Rezai . 2005. Estimation of genetic parameters and combining ability for yield and yield components in bread wheat. Journal of Science and Technology in Agriculture and Natural Resources 9(1):157-171.

10. Kulshreshtha N and KN Singh. 2011. Combining ability studies in wheat (Triticum aestivum L.) for genetic improvement under salt stress. Journal of Wheat Research 3(2): 22-26.

11. Kumar Anil, Harshwardhan, Kumar Amarjeet, and B Prasad. 2015a. Combining ability and gene interaction study for yield, its attributing traits and quality in common wheat. Journal of Applied and Natural Science 7: 927-934.

12. Kumar Ashutosh, VK Mishra, RP Vyas and V Singh 2010. Heterosis and combining ability analysis in bread wheat (Triticum aestivum L.). Journal of Plant Breeding and Crop Science 3(10): 209-217. 
13. Kumar J, SK Singh, L Singh, A Kumar, Anurag, SK Singh and M Kumar. 2016a. Estimates of general and specific combining ability for grain yield and other physiological characters in bread wheat under late sown condition. Research in Environment and Life Sciences 9:784-789.

14. Panse VG and PV Sukhatme. 1967. Statistical Methods of Agricultural Workers. 2nd Endorsement, ICAR Publication, New Delhi, India, pp., 381.

15. Romanus KG, S Hussein and WP Mashela. 2008. Combining ability analysis and association of yield and yield components among selected cowpea lines. Euphytica 162: 205-210.

16. Siddique M, S Ali, MFA Malik and SI Awan. 2004. Combining ability estimates for yield and yield components in spring wheat. Sarhad Journal of Agriculture 20(4):485-487.
17. Singh MK, PK Sharma, BS Tyagi and G Singh. 2014. Combining ability analysis for yield and protein content in bread wheat (Triticum aestivum L.). Indian Journal of Agriculture Sciences 84:328-36.

18. Singh RK and BD Chaudhary. 1979. Biometrical Methods in Quantitative Genetics Analysis. Kalyani Publisher, New Delhi. Pp., 318.

19. Srivastava MK, D Singh and S Sharma. 2012. Combining ability and gene action for seed yield and its components in bread wheat (Triticum aestivum L.). Electronic Journal of Plant Breeding 3(1):606-611. 